\title{
PENGEMBANGAN DESA WISATA PENDIDIKAN DI DESA CIBODAS, KABUPATEN BANDUNG BARAT
}

\author{
Encang Saepudin', Agung Budiono², dan Mas Halimah ${ }^{3}$ \\ 1,2Program Studi Ilmu Perpustakaan, Fakultas Ilmu Komunikasi, Universitas Padjadjaran \\ ${ }^{3}$ Program Studi Administrasi Publik, Fakultas Ilmu Sosial dan Ilmu Politik, Universitas Padjadjaran \\ E-mail: encang@unpad.ac.id
}

\begin{abstract}
ABSTRAK. Tujuan penelitian adalah untuk mengetahui proses pengembangan desa wisata pendidikan berdasarkan pada potensi produk wisata. Penelitian ini menggunakan metode kualitatif dengan pendekatan studi kasus. Proses pengumpulan data yang digunakan adalah wawancara, observasi, $F G D$, dan studi pustaka. Teknik analisis data deskriptif dengan tahapan reduksi data, penyajian data, dan penarikan kesimpulan. Uji Validitas dan reliabilitas melalui proses triangulasi sumber. Informan dalam penelitian ini adalah pihak pemerintah ( 3 orang), tokoh masyarakat dan agama (5 orang), dan pengelola desa wisata (5 orang). Jumlah responden 13 orang. Hasil penelitian menunjukkan bahwa model pengembangan desa wisata pendidikan di Desa Cibodas memiliki enam strategi yaitu (a) peningkatan partisipasi aktif masyarakat dalam pengembangan desa wisata (b) pengembangan desa wisata yang khas berdasarkan kepada potensi alam, sosial, dan budaya masyarakat setempat; (c) pengembagan kapasitas lembaga masyarakat sebagai lembaga pengelola desa wisata (d) pengembangan media promosi wisata; (e) peningkatan sumberdaya manusia melalui program pendidikan dan pelatihan yang terstruktur dan terorganisasi; (f) pendampingan yang dilakukan secara terstruktur dari lembaga/ dinas terkait.
\end{abstract}

Kata Kunci: desa wisata; wisata pendidikan; pariwisata

\section{DEVELOPMENT OF EDUCATION TOURISM IN CIBODAS VILLAGE IN WEST BANDUNG REGENCY.}

\begin{abstract}
The aim of the study was to find out the development strategy of the education tourism based on the potential of tourism products. This study uses qualitative methods with a case study approach. The data was gathered by interviews, observation, FGD, and literature studies. The data was analyzed with the stages of data reduction, data presentation, and conclusion drawing. Data validity and reliability were tested through the source triangulation process. The informants in this study were the government officers (3 people), community and religious leaders (5 people), and tourism village managers (5 people). The number of respondents is 13 people. The results of the study show that the model of rural tourism education development in Cibodas Village has six strategies, namely (a) developing the active participation of the community in the development of tourism villages (b) the development of a typical tourism village based on the natural, social and cultural potential of the local community; (c) developing the capacity of community institutions as tourism village management institutions (d) developing tourism promotion media; (e) improving human resources through structured and organized education and training programs; (f) mentoring which was conducted structurally by related institutions / agencies.
\end{abstract}

Keywords: village tourism; education tourism; tourism

\section{PENDAHULUAN}

Pengembangan agrowisata selain berfungsi sebagai peningkatan konservasi lingkungan, juga berfungsi sebagai pengembangan ekonomi masyarakat. Pengembangan wisata berbasis masyarakat merupakan upaya strategis untuk memberdayakan masyarakat. Sinergi antara keindahan alam, budaya masyarakat, dan kehidupan pertanian akan menjadi daya tarik wisata suatu daerah. Selain itu, dengan berkembangnya wisata pedesaan di suatu daerah akan memberikan manfaat untuk meningkatkan kesejahteraan masyarakat dan pendapatan pemerintah (Aprilia, 2015). Apabila mengacu kepada pedoman desa wisata yang dikeluarkan oleh Departemen Kebudayaan dan Pariwisata pengembangan desa wisata ini harus disertai oleh wisata pendidikan. Berdasarkan hal tersebut, desa wisata harus pula menjadi desa wisata pendidikan.

Perkembangan pariwisata yang cenderung mengarah ke wisata massal, seringkali menimbulkan beragam dampak negatif yang tidak disadari. Dampak wisata massal dapat menimbulkan degradasi bahkan destruksi atas lingkungan, baik lingkungan alam maupun lingkungan budaya dan sosial. Berdasrkan dampak tersebut, sebagain orang berkeinginan untuk mencari alternatif wisata baru yang dirasa lebih sustainable dan minim dampak negatif. Oleh karena itu, sejak tahun 1980, terjadi pergeseran minat wisatawan yang mengarah pada pilihan wisata yang lebih ramah lingkungan. Seiring dengan perkembangan tersebut, minat terhadap wisata yang menawarkan pengalaman wisata edukasi juga ikut meningkat (Prastiwi, 2016).

Wisata pendidikan merupakan konsep wisata yang menyuguhkan perpaduan antara konsep pendidikan nonformal dengan wisata (hiburan) kepada wisatawan. Dalam konsep ini, ketika wisatawan berkunjung selain mendapatkan hiburan (rekreasi) juga memperoleh pengalaman/ belajar dengan metode yang menyenangkan. Melalui edutainment pembelajaran akan lebih cepat difahami oleh para pengunjung. Hal ini sejalan dengan pendapat Rodger, Ia menyatakan bahwa pariwisata pendidikan merupakan suatu program dimana peserta kegiatan 
wisata melakukan perjalanan wisata pada suatu tempat tertentu dalam suatu kelompok dengan tujuan utama mendapatkan pengalaman belajar secara langsung terkait lokasi yang dikunjungi. (Rodger, 1998: 28)

Menurut Ritchie (2003) wisata edukasi adalah " $a$ tourist activity undertaken by those who are undertaking an overnight vacation and those who are undertaking an excursion for whom education and learning is a primary or secondary part of their trip". Dari pernyataan tersebut, dapat disimpulkan bahwa wisata edukasi adalah kegiatan wisata yang dilakukan oleh individu atau kelompok ke suatu tempat dengan tujuan mendapatkan pengalaman pembelajaran.

Ritchie (2003) dalam sumber yang sama melihat wisata edukasi sebagai sebuah produk, proses, dan fungsi. Sebagai sebuah produk, penekanannya adalah pada hasil dari pengalaman belajar, jika dilihat sebagai sebuah proses atau fungsi, fokusnya adalah pada cara untuk mencapai tujuan yang diinginkan. Wisata edukasi juga dapat dilihat sebagai sebuah kategori dari wisata alternatif (alternatif dari wisata massal yang konvensional, terstandar dan berskala besar) dan merupakan subbagian dari wisata minat khusus (Saefulloh dan Darma, 2014). Wisata yang termasuk dalam wisata edukasi adalah ekowisata, wisata sejarah, wisata pedesaan/pertanian, pertukaran pelajar antar institusi pendidikan, wisata studi banding, kegiatan universitas dalam dan luar negeri, dan kegiatan study tour sekolah. Selain itu, ditambahkan oleh Yusuf (2016) bahwa destinasi wisata edukasi bisa berupa daerah dengan kekayaan alam ataupun keunikan hasil buatan manusia.

Berdasarkan beberapa pengertian diatas, wisata pendidikan merupakan perpaduan dari unsur learning dan enriching. Kedua unsur ini merupakan hal yang harus ada pada setiap kegiatan wisata. Dengan konsep ini para wisatawan memiliki kesempatan untuk memperoleh pengetahuan dan pengalaman baru disamping kesenangan di objek wisata. Mendapatkan Learning Experience melalui pengetahuan baru adalah hal yang abadi dan mampu meningkatkan hidup seseorang atau Expansion Life (Hasanah, 2015).

Wisata edukasi akan bermanfaat apabila pengunjung/ wisatawan memperoleh pengetahuan dan pengalaman baru disamping kesenangan di objek wisata. Oleh karenanya, dalam wisata edukasi, perlu diterapkan prinsip 3E sebagai berikut (Sharma, 2015);

a. Faktor lingkungan (environmental factors)

Faktor lingkungan dapat berupa suasana tempat tinggal atau lingkungan belajar. Lingkungan tersebut harus nyaman dan dapat mendukung kelancaran aktivitas wisata. Untuk menciptakan kenyamanan bagi wisatawan pada saat melakukan kegiatan wisata, harus didukung dari lingkungan fisik dan lingkungan sosial. Lingkungan fisik adalah keadaan yang tampak di sekitar objek wisata, yang akan mempengaruhi secara langsung maupun tidak langsung dalam kegiatan wisata. Lingkungan fisik dapat berupa suasana alam yang asri, lingkungan yang bersih, jauh dari polusi dan sampah. Sedangkan lingkungan sosial bisa berupa sikap masyarakat dalam menerima dan melayani kunjungan tamu, sikap ramah dan sopan-santun, serta sikap masyarakat yang menimbulkan rasa aman bagi wisatawan.

b. Keikutsertaan (engagement)

Tujuan utama seseorang melakukan wisata edukasi adalah untuk mendapatkan pengalaman pembelajaran. Oleh karena itu, dalam wisata edukasi wisatawan ikut berpartisipasi aktif dan dilibatkan dalam kegiatan wisata, namun tanpa mengganggu ketertarikan atau preferensi mereka. Wisatawan dilibatkan di dalam kegiatan agar mereka lebih mampu menyerap ilmu dan pesan yang disampaikan, sehingga mereka dapat mempraktekkan dalam kehidupan sehari-hari. Proses belajar akan menjadi lebih mudah dengan keterlibatan wisatawan secara langsung didalamnya. Keikutsertaan atau keterlibatan wisatawan dalam setiap kegiatan merupakan inti dari proses pembelajaran.

c. Eksplorasi (exploration)

Eksplorasi memberikan pembelajaran secara langsung kepada wisatawan mengenai tempat tersebut. Dengan eksplorasi, wisatawan dapat lebih menggali informasi yang mereka butuhkan, dengan melihat langsung objek tersebut di lapangan. Namun, sebelum melakukan kegiatan eksplorasi, terlebih dahulu dilakukan kegiatan pengarahan terhadap wisatawan yang diberikan oleh pengelola desa wisata. Pengarahan dilakukan untuk memberikan pengetahuan dasar, sedangkan eksplorasi akan memberikan pengetahuan dan pemahaman lebih mendalam melalui pengalaman yang didapat di lapangan.

Dalam UU Kepariwisataan nomor 10 Tahun 2009 pasal 23 ayat $1 \mathrm{C}$ menjelaskan bahwa "Pemerintah dan Pemerintah Daerah berkewajiban memelihara, mengembangkan, dan melestarikan aset nasional yang menjadi daya tarik wisata dan aset potensial yang belum tergali". Potensi dan daya tarik wisata yang ada di Desa Cibodas merupakan aset potensial yang perlu dikembangkan. Sesuai dengan undang-undang tersebut, pemerintah setempat berkewajiban untuk mengembangkannya.

Pengembangan desa wisata sebagai aset kepariwisataan dan aset ekonomi perlu memegang prinsip (1) tidak bertentangan dengan budaya setempat, (2) pembangunan fasilitas ditujukan untuk meningkatkan kualitas lingkungan, dan (3) pemebrdayaan masyarakat. Oleh karena itu, pengembangan desa wisata Cibodas harus memperhatikan berbagai aspek yang berkaitan dengan kehidupan sosial, budaya, dan mata pencaharian masyrakat. Berdasarkan kepada uraian di atas, permasalah utama dalam penelitian ini adalah bagaimana strategi pengembangan desa wisata pendidikan di Desa Cibodas Kabupaten Bandung Barat. 


\section{METODE}

Metode yang digunakan yaitu kualitatif (Travers, 2001). Pemilihan pendekatan ini dengan pertimbangan bahwa sifat data penelitian mampu mempertahankan keutuhan dari obyek, artinya berbagai data yang berkaitan dengan penelitian dipahami sebagai satu kesatuan yang terintegrasi. Melalui metode ini, pemaparan data hasil penelitian akan dilakukan secara deskriptif berdasarkan fakta secara kualitatif. Data yang diuraikan sesuai dengan fakta hasil kajian lapangan.

Sumber data dalam penelitian ini adalah 13 orang dengan rincian sebagai berikut pihak pemerintah 3 orang, tokoh masyarakat dan agama 5 orang, dan pengelola desa wisata 5 orang. Mereka berperan sebagai informan yang bertindak langsung sebagai pengelola pengembangan desa wista. Teknik pengambilan data dilakukan dengan cara wawancara dan observasi secara langsung terhadap aktivitas masyarakat dalam pengembangan desa wisata. Wawancara dilakukan secara tidak berstruktur; bentuknya bisa dialog, diskusi, bincang santai, atau tanya jawab. Data hasil penelitian lapangan selanjutnya diolah, disusun, dan dianalisis sehingga data memiliki nilai bagi kehidupan masyarakat.

Untuk menambah wawasan penelitian ini, dilakukan kajian pustaka terkait permasalahan pengembangan desa wisata terutama berkaitan dengan konteks strategi dan proses pengembangan desa wisata. Konsep dan teori tentang kriteria desa wisata akan dijadikan dasar dalam analisis dan pembahasan data penelitian. Konteks tersebut terkait dengan kenyataan yang terkait dengan produk dan daya tarik wisata, kesiapan dan penerimaan masyarakat, pengembangan sumberdaya manusia, dan ketersediaan ruang untuk pengembangan fasilitas pendukung wisata merupakan data primer yang diperoleh dan dijadikan dasar dalam pengolahan data hasil penelitian.

\section{HASIL DAN PEMBAHASAN}

Potensi obyek dan daya tarik wisata merupakan modal dasar bagi pengembangan suatu kawasan pedesaan menjadi desa wisata. Potensi tersebut dapat berupa potensi fisik lingkungan alam dan potensi sosial budaya (Putra, 2012). Berdasarkan pada hal tersebut Desa Cibodas memiliki potensi besar sebagai desa wisata baik dari segi potensi fisik lingkungan alam maupun potensi sosial budaya. Berdasarkan data profil Desa Tahun 2016 luas Desa Cobodas 988,77 ha terdiri dari (1) daerah permukiman 113,50 ha, (2) tanah ladang 695,27 ha, dan (3) pekarangan 180 ha. Jumlah penduduk desa adalah 11,206 orang yang terdiri atas 5655 orang laki-laki dan perempuan 5551 orang. Beberapa jenis tanaman yang menjadi andalan para petani adalah tomat, cabe, kubis, dan lain-lain.

Selain bergerak dalam bidang pertanian, para penduduk desa juga bergerak dalam bidang peternakan.
Ternak yang menjadi ungulan penduduk desa adalah sapi, ayam kampung, dan domba. Tingkat kesejahteraan masyarakat desa Cibodas cukup tinggi. Hal ini terlihat dari data keluarga prasejahtera yang hanya mencapai $24.8 \%$. atau 381 keluarga dari 1535 keluarga. Selain itu, tingkat kesejahteraan masyarakat ini terlihat dari penghasilan percapita dari setiap keluarga. Penghasilan percapita keluarga bisa dilihat dari sektor pertanian, peternakan, dan industri kecil menengah.

Berdasarkan peraturan daerah nomor 14 tahun 2012 tentang rencana induk pembangunan kepariwisataan Bandung Barat, potensi pariwisata desa Cibodas dapat di gambarkan sebagai berikut;

1. Daya tarik wisata; Potensi utama desa Cibodas adalah agrowisata, berupa lahan dan hasil pertanian (Pertanian mulai dari pembibitan, penanaman, pemeliharaan, masa panen, dan pasca panen; Peternakan, pemeliharaan, budidaya, dan olahan hasil peternakan); wisata pendidikan khusus pertanian mulai dari pembibitan sampai pengolahan hasil pertanian;

2. Aksesibilitas; Jalur menuju desa wisata Cibodas sudah cukup memadai namun masih terdapat titiktitik yang perlu diperbaiki; rambu-rambu menuju desa wisata wudah tersedia namun masih terbatas.

3. Fasilitas; Tersedia homestay berjumlah 44 rumah. Masing-masing rumah memiliki daya tampung 8-10 orang; tersedia pusat oleh-oleh dan cinderamata, rumah makan, dan aula.

4. Pemberdayaan masyarakat; Partisipasi masyarakat dalam pelaksanaan desa wisata sudah cukup tinggi, namum masih terbatas pada beberapa sektor; sudah terbangun kesadaran masyarakat Desa Cibodas sebagai tuan rumah yang baik dalam menerima para wisatawan.

5. Pemasaran dan promosi; Promosi dilakukan hanya sebatas informasi dari orang ke orang.

6. Kelembagaan dan sumber daya manusia; Sudah ada peraturan daerah tentang rencana induk pembangunan kepariwisataan Bandung Barat (Perda nomor 14 tahun 2012); sudah terbentuk lembaga kemasyarakatan yang mengelola desa wisata. Lembaga tersebut domotori oleh Kelompok tani Mekar Tani Jaya

Untuk menyusun strategi pengembangan desa wisata Cibodas, dilakukan analisis SWOT berdasarkan potensi pariwisata yang dimiliki oleh Desa Cibodas. Analisis ini dilakukan untuk menggambarkan strategi yang paling tepat di dalam perencanaan pengembangan desa wisata. Berikut ini adalah gambaran hasil analisis SWOT dan gambaran strateginya.

Berdasarkan hasil analisis SWOT yang telah dilakukan terdapat enam strategi yang bisa dilakukan dalam pengembangan desa wista yaitu;

1. peningkatan partisipasi aktif masyarakat dalam pengemabagan desa wisata mulai dari tahap perencanaan, peraksanaan, sampai pada tahap evaluasi program; 
Tabel 1. Analisis SWOT pengembangan desa wisata pendidikan

\begin{tabular}{|c|c|c|}
\hline Ekternal & Strength (S) & Weakness (W) \\
\hline & $\begin{array}{l}\text { 1. Daya tarik objek wisata yang menarik dan } \\
\text { alami } \\
\text { 2. Sikap masyarakat cenderung ikut } \\
\text { berpartisipasi } \\
\text { 3. Terdapat kelompoka pengelola desa wisata } \\
\text { (kompepar) yang dimotori oleh SP4S } \\
\text { 4. Keterbukaan masyarakat terhadap pengunjung } \\
\text { 5. Pasilitas wisata sudah cukup }\end{array}$ & $\begin{array}{l}\text { 1. Keikutsertaan masyarakat dalam pengembangan } \\
\text { desa wisata masih bersifat pelaksana (Objek } \\
\text { belum subjek) } \\
\text { 2. Tingkat pendidikan masyarakat masih } \\
\text { rendah yang berpengaruh pada keberhasilan } \\
\text { pengembangan desa wisata } \\
\text { 3. Belum maksimalnya upaya promosi }\end{array}$ \\
\hline Opportunity (O) & Strategi SO & Srategi WO \\
\hline $\begin{array}{l}\text { 1. } \begin{array}{l}\text { Adanya regulasi dari } \\
\text { pemerintah yang } \\
\text { mendorong perkembangan } \\
\text { pariwisata }\end{array} \\
\text { 2. Adanya kepedulian dari } \\
\text { CSR perusahaan dan } \\
\text { perguruan tinggi } \\
\text { 3. Pasar wisata yang masih } \\
\text { terbuka luas }\end{array}$ & $\begin{array}{l}\text { 1. Meningkatkan partisipasi masyarakat dalam } \\
\text { pengembangan desa wisata mulai tahap } \\
\text { perencanaan, pelaksanaan, dan evaluasi. } \\
(\mathrm{S} 1+\mathrm{S} 2+\mathrm{S} 3+\mathrm{S} 4+\mathrm{S} 5+\mathrm{O} 1+\mathrm{O} 2+\mathrm{O} 3) \\
\text { 2. Mengembangkan produk wisata yang } \\
\text { khas berdasarkan kepada potensi alam, } \\
\text { sosial, dan budaya masyarakat setempat } \\
\text { (S1+S4+O1+O} 2+\mathrm{O} 3) \\
\text { 3. Pengembagan kapasiatas lembaga masyarakat } \\
\text { sebagai lembaga pengelola desa wisata } \\
\text { (kompepar) }(\mathrm{S} 2+\mathrm{S} 3+\mathrm{S} 4+\mathrm{S} 5+\mathrm{O} 1) \\
\text { 4. Pengembangan media promosi wisata malalui } \\
\text { beragai media }(\mathrm{S} 1+\mathrm{S} 2+\mathrm{O} 2+\mathrm{O} 3)\end{array}$ & $\begin{array}{l}\text { 1. Pendampingan kepada masyarakat untuk } \\
\text { mengawal proses pengembangan desa wisata } \\
\text { (W1+W2+W3+O1) } \\
\text { 2. Peningkatan sumberdaya manusia melalui } \\
\text { program pendidikan dan pelatihan yang } \\
\text { terstruktur (W1+W2+W3+O2+O3) }\end{array}$ \\
\hline Threat (T) & Strategi ST & \\
\hline $\begin{array}{l}\text { 1. Kurangnya koordinasi antar } \\
\text { SKPD } \\
\text { 2. Kurangnya koordinasi } \\
\text { antar Pemerintah dengan } \\
\text { masyarakat }\end{array}$ & $\begin{array}{l}\text { 1. Membangun alur komunikasi melalui } \\
\text { peningkatan kapasitas kelompok pengembang } \\
\text { desa wisata }(\mathrm{S} 2+\mathrm{S} 3+\mathrm{T} 1+\mathrm{T} 2)\end{array}$ & $\begin{array}{l}\text { Memberi penyuluhan kepada masyarakat desa } \\
\text { wisata mengenai pentingnya pengembangan } \\
\text { desa wisata dalam meningkatkan kesejahteraan } \\
\text { masyarakat } \\
(\mathrm{W} 1+\mathrm{W} 2+\mathrm{W} 3+\mathrm{T} 1+\mathrm{T} 2)\end{array}$ \\
\hline
\end{tabular}

2. pengembangan desa wisata yang khas berdasarkan kepada potensi alam, sosial, dan budaya masyarakat setempat;

3. pengembangan kapasitas lembaga masyarakat sebagai lembaga pengelola desa wisata (kompepar) untuk membangun koordinasi dan komunikasi antara pemerintah, masyarakat, dan lembaga donor;

4. pengembangan promosi wisata malalui beragai media;

5. peningkatan sumberdaya manusia melalui program pendidikan dan pelatihan yang terstruktur dan terorganisai;

6. pendampingan dilakukan secara terstruktur dari lembaga-lembaga/ dinas terkait

Strategi yang dikemukan di atas sejalan dengan Undang-undang nonor 10 tahun 2009 tentang Kepariwisataan terutama bab IV mengenai Pembangunan Kepariwisataan pasal 7 menyatakan bahwa pembangunan kepariwisataan meliputi empat komponen utama yakni industri pariwisata, destinasi wisata, pemasaran, dan kelembagaan kepariwisataan. Undang-undang nomor 10 tahun 2009 ini ditindaklanjuti oleh pemerintah daerah Kabupaten Bandung Barat dengan mengeluarkan peraturan daerah nomor 07 tahun 2013 tentang Penyelenggaraan Kepariwisataan Daerah. Dalam peraturan daerah tersebut disebutkan kompenen-kompnen utama dalam pengembangan parwisata daerah yakni industri pariwisata, destinasi, promosi, dan kelembagaan kepariwisataan.

Hal tersebut ditegaskan pula di dalam peraturan daerah Kabupaten Bandung Barat nomo 04 tahun 2012 tentang Rencana Induk Pembangunan Kepariwisataan Kabupaten Bandung Barat terutama pada bab
IV tentang strategi pembangunan kepariwisataan pasal 11 menyatakan bahwa strategi pembangunan kepariwisataan dilaksanakan melalui empat sektor pembangunan yaitu industeri, destinasi, promosi, dan kelembagaan kepariwisataan.

Berikut ini akan digambarkan mengenai strategi pengembangan desa wista sesuai dengan komponenkomponen pembangunan kepariwisataan daerah;

1. Peningkatan Partisipasi Masyarakat Desa Wisata Partisipasi masyarakat dalam pengembangan desa wiasata mutlak diperlukan. Keberhasilan pengembangan desa wisata tidak mungkin tercapai tanpa partisipasi masyarakat. Masyarakat setempat dengan pengetahuan serta pengalamannya menjadi modal yang sangat besar dalam melaksanakan pengembangan desa wisata. Hal ini sejalan dengan pendapatnya Batubara (2017) menyatakan bahwa partisipasi bukan hanya sekadar salah satu tujuan dari pembangunan sosial tetapi merupakan bagian yang integral dalam proses pembangunan sosial. Partisipasi masyarakal berarti eksistensi manusia seutuhnya.

Meningkatkan partisipasi dalam pengembangan desa wisata harus dilakukan dengan cara meningkatkan keterlibatan warga secara langsung dalam berbagai tahapan kegiatan mulai dari perencanaan, pelaksanaan, sampai pada tahapan evalusi program. Untuk membangun keterlibatan masyarakat dalam sebuah program pembangunan diperlukan tiga unsur pokok yaitu adanya kemauan, kesempatan, dan kemampuan untuk berpatisipasi. Yuliastuti (2013) mengemukakan bahwa tumbuh dan berkembangnya partisipasi masyarakat dalam sebuah program bergantung pada kemauan masyarakat untuk berpartisipasi, kesempatan yang 
diperoleh untuk berpartisipasi, dan kemampuan untuk berpartisipasi.

Kemauan untuk berpartisipasi merupakan kunci utama bagitumbuh dan berkembangnya partisipasimasyarakat dalam pengembangan desa wista. Kesempatan dan kemampuan yang cukup, tidak menjadi jaminan untuk tumbuh dan berkembangnya partisipasi masyarakat. Apabila masyarakat memiliki kemampuan dan sudah diberi kesempatan untuk berpartisipasi namun secara internal tidak memiliki kemauan maka partisipasinya akan rendah. Naum sebaliknya apabila kemampuan dan kesempatan terbatas tetapi memiliki kemauan akan mendorong seseorang untuk meningkatkan kemampuan dan aktif memburu serta memanfaatkan setiap kesempatan (Yustina dan Naria, 2008).

Partisipasi masyarakat pada tahap perencanaan kegiatan pengembangan desa wisata dapat dilihat dari kehadiran masyarakat pada proses perencanaan program yang dilakukan oleh pengelola desa wisata. Kehadiran masyarakat dalam pertemuan yang dilakukan oleh pengelola desa wisata terkadang didak sesuai dengan waktu luang dari para warga yang diundang. Partisipasi masyarakat dalam pelaksanaan kegiatan dapat dilihat dari keterlibatan masyarakat pada kegiatan fisik dan non fisik terutama dibidang ekonomi. Partisipasi masyarakat dalam penyediaan sarana yang mendukung pelaksaan kegiatan pengembangan desa wisata cukup bagus. Hal ini terlihat dari tingginya kesadaran masyarakat dalam membantu menyediakan fasilitas wisata seperti homestay. Pada tahap evaluasi partisipasi masyarakat dapat dilihat dari perhatian terhadap perawatan ataupun pemeliharaannya secara berkala pada semua fasilitas yang ada. Partisipasi masyarakat dalam program ini dilihat dari seberapa aktif masyarakat dalam memelihara, menjaga, merawat seluruh sarana yang ada.

2. Pengembangan desa wisata yang khas berdasarkan kepada potensi alam, sosial, dan budaya masyarakat setempat

Potensi obyek dan daya tarik wisata merupakan modal dasar bagi pengembangan suatu kawasan pedesaan menjadi desa wisata. Potensi tersebut dapat berupa potensi fisik lingkungan alam dan potensi sosial budaya (Putra, 2012). Berdasarkan pada hal tersebut dapat digambarkan potensi desa Cibodas sebagai desa wisata dari segi potensi fisik lingkungan alam dan potensi sosial budaya sebagai berikut. Wilayah Cibodas merupakan daerah perbukitan di Kecamatan Lembang Kabupaten Bandung Barat dengan ketinggian 1260 meter di atas permukaan laut. Mayoritas penduduknya berpenghasilan dari pertanian. Komoditi di pasar Caringin Bandung dan pasar induk Tangerang merupakan produk hasil sayuran dari desa Cibodas yang mencapai sekitar 100 ton/ hari. Sekitar 695,27 ha ladang yang ada di Cibodas yang menghasilkan komoditas pertanian berupa sayuran, umbi-umbian, dan buah-buahan. Selain itu, terdapat beberapa sumber mata air yang tidak pernah mengering, sekalipun musim kemarau.

Berdasrkan kepada potensi alam dan sosial budaya yang dimiliki desa Cibodas, pengembangan wisata pendidikan bidang pertanian memiliki peluang yang sangat besar. Keinginan masyarakat untuk memperoleh hiburan sekaligus mendapat pengetahuan baru merupakan peluang besar bagi pengembangan desa wista pendidikan. Peluang ini terjadi karena adanya kejenuhan dalam pengembangan pendidikan di dalam ruangan. Proses pembelajaran didalam kelas bersifat kaku dan formal sehingga pendidikan di dalam kelas dapat menciptakan rasa bosan atau rasa jenuh. Oleh karena itu, edutainment dapat dijadikan suatu alternatif dalam meningkatkan pengetahuan, pengalaman, dan keterampilan melalui proses hiburan (wisata). Proses kolaborasi unsur pendidikan dan wisata bisa dilakukan melalui kegiatan wisata pendidikan.

Seperti telah disebutkan dalam pembahasan sebelumnya bahwa wisata pendidikan merupakan konsep wisata yang menyuguhkan perpaduan antara konsep pendidikan nonformal dengan wisata (hiburan) kepada wisatawan. Dalam konsep ini, ketika wisatawan berkunjung selain mendapatkan hiburan (rekreasi) juga memperoleh pengalaman/ belajar dengan metode yang menyenangkan. Selain itu, wisata pendidikan merupakan perpaduan dari unsur learning dan enriching. Kedua unsur ini merupakan hal yang harus ada pada setiap kegiatan wisata pendidikan. Dengan konsep ini para wisatawan memiliki kesempatan untuk memperoleh pengetahuan dan pengalaman baru disamping kesenangan di objek wisata. Mendapatkan Learning Experience melalui pengetahuan baru adalah hal yang abadi dan mampu meningkatkan hidup seseorang atau Expansion Life (Kwartolo, 2007).

Berdasrkan pada konsep tersebut maka didalam pengembangan desa wisata pendidikan di daerah Cibodas bisa berdasarkan kepada prinsip 3E yakni environmental factors, engagement, dan exploration (Sharma, 2015: 14-15).

a. Faktor lingkungan (environmental factors)

Faktor lingkungan dapat berupa suasana tempat tinggal atau lingkungan belajar. Lingkungan tersebut harus nyaman dan dapat mendukung kelancaran aktivitas wisata. Untuk menciptakan kenyamanan bagi wisatawan pada saat melakukan kegiatan wisata, harus didukung dari lingkungan fisik dan lingkungan sosial. Lingkungan fisik adalah keadaan yang tampak di sekitar objek wisata. Lingkungan fisik dapat berupa suasana alam sekitar, kebersihan dan kesehatan lingkungan. Lingkungan sosial berasal dari masyarakat sekitar, antara lain sikap masyarakat dalam menerima dan melayani kunjungan tamu, sikap ramah dan sopan-santun, serta sikap masyarakat yang menimbulkan rasa 
aman bagi wisatawan. Apabila lingkungan fisik dan sosial terbangun dengan baik maka pengembangan desa wista akan mudah tercapai. Faktor lingkungan ini akan menjadi penentu kualitas pelayanan desa wisata pendidikan di Cibodas. Hal ini bisa dilihat pada bagan di bawah ini;

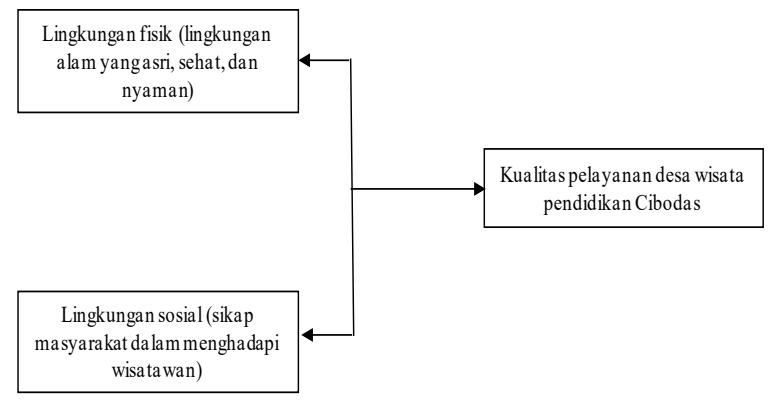

Gambar 1. Faktor Lingkungan Desa Cibodas

\section{b. Keikutsertaan (engagement)}

Tujuan utama seseorang melakukan wisata edukasi adalah untuk mendapatkan pengalaman pembelajaran. Oleh karena itu, dalam wisata edukasi wisatawan harus diikutsertakan secara aktif dalam kegiatan wisata. Keikutsertaan atau keterlibatan wisatawan dalam setiap kegiatan merupakan inti dari proses pembelajaran.

Upaya untuk melibatkan para wisatawan dalam proses pembelajaran yakni dengan membuat paket wisata. Paket wisata disusun didasarkan kepada kelompok target sasaran. Oleh karena itu, para pengelola harus secara rinci membuat paket wisata ini didasarkan kepada kelompok sasaran tersebut. Misalnya, paket wista untuk tingat pelajar akan berbeda dengan paket wisata untuk tingkat mahasiswa atau masyarakat umum. Pengemasan paket wisata harus didasarkan kepada unsur kekuatan/ keunggulan dari wisata pendidikan bidang pertanian.

Sebagai contoh berikut gambaran paket wisata yang bisa dibuat oleh para pengelola desa wisata Cibodas.

Tabel 2 Paket Wisata Cibodas

\begin{tabular}{llll}
\hline Hari & Waktu & Kegiatan & Penggung jawab \\
\hline 1 & $08.00-10.00$ & Cek in Homestay & Panitia \\
$10.00-12.00$ & $\begin{array}{l}\text { Pengenalan } \\
\text { lingkungan desa } \\
\text { Cibodas }\end{array}$ & Tour guide \\
& & Panitia \\
$12.00-13.30$ & $\begin{array}{l}\text { Istirahat, makan, } \\
\text { solat }\end{array}$ & Tour guide, \\
$13.30-15.00$ & $\begin{array}{l}\text { Pengenalan } \\
\text { pembibitan }\end{array}$ & pengelola \\
& Panitia \\
$15.00-16.00$ & $\begin{array}{l}\text { Istirahat } \\
\text { Pengenalan } \\
\text { pemeliharaan } \\
\text { tanaman }\end{array}$ & $\begin{array}{l}\text { Tour guide, } \\
\text { pengelola }\end{array}$ \\
& $\begin{array}{l}\text { Intirahat, makan, dan } \\
\text { solat } \\
17.30-19.30\end{array}$ & $\begin{array}{l}\text { Panitia } \\
\text { (pengenalan seni } \\
\text { budaya) }\end{array}$ & $\begin{array}{l}\text { Tour guide, } \\
\text { pengelola }\end{array}$ \\
&
\end{tabular}

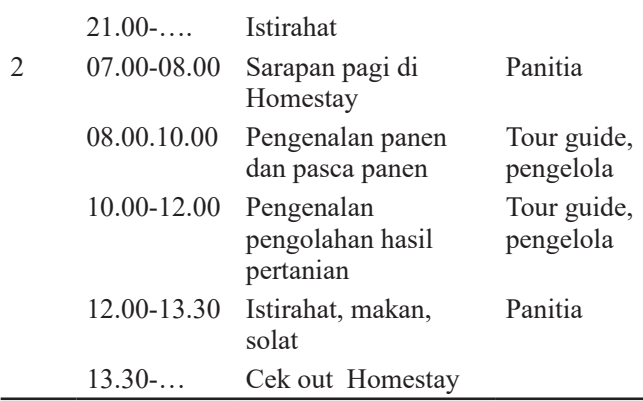

c. Eksplorasi (exploration)

Eksplorasi memberikan pembelajaran secara langsung kepada wisatawan mengenai objek wisata yang disuguhkan. Dengan eksplorasi, wisatawan dapat lebih menggali informasi yang mereka butuhkan, dengan melihat langsung objek tersebut di lapangan. Namun, sebelum melakukan kegiatan eksplorasi, terlebih dahulu dilakukan kegiatan pengarahan terhadap wisatawan. Pengarahan dilakukan untuk memberikan pengetahuan dasar, sedangkan eksplorasi akan memberikan pengetahuan dan pemahaman lebih mendalam melalui pengalaman yang didapat di lapangan.

Proses eksplorasi pada dasarnya sudah dirancang oleh pengelola desa wisata dengan menyuguhkan paket wisata pertanian mulai dari masa pembibitan sampai pada pengolahan hasil pertanian. Melalui pendampingan oleh tour guide dan pengelola desa wisata, para wisatawan disuguhkan berbagai kosnsep dan praktek berkaitan dengan proses bertani. Dalam hal ini, para wisatawan selain memperoleh pengetahuan dari para tour guide dan pengelola desa wisata, mereka pun memperoleh pengalaman langsung ketika ikut serta dalam praktek bertani.

3. Pengembagan kapasitas lembaga masyarakat sebagai lembaga pengelola desa wisata (kompepar) Untuk menjaga penerimaan dan komitmen masyarakat terhadap kegiatan kepariwisataan diperlukan kelembagaan yang kuat sebagai kontrol terhadap berjalannya proses pengembangan wisata di daerah tersebut. Dengan kata lain kelembagaan yang mendukung pengembangan dan pengelolaan desa wisata menjadi faktor pendukung keberhasilan pengembangan desa wisata. Kelembagaan merupakan wadah bagi masyarakat untuk berkoordinasi dan berkomunikasi dalam pengembangan diri maupun kelompok. Hal ini terjadi karena pembangunan kelompok ini didasarkan kepada kebutuhan masyarakat dan untuk menyelesaikan permasalahan yang dihadapi masyarakat. Pembentukan kelompok ini sejalan dengan pendapat Friedman (1993) dalam Prijono dan Pranarka (1996:138) yang menjelaskan bahwa proses pemberdayaan dapat dilakukan secara individual maupun kolektif 
(kelompok). Organisasi yang sudah dibangun dalam program pengembangan desa wisata adalah Pusat Pelatihan Pertanian \& Pedesaan Swadaya (P4S) Mekar Tani Jaya.

\section{Promosi wisata malalui berbagai media}

Pengelola pariwisata harus melakukan promosi produk wisata agar produk ini dapat diketahui oleh masyarakat luas. Melalui promosi produk wisata akan lebih dikenal oleh masyarakat. Suryadana dan Octavia (2015) yang dikutip oleh Utama (2017) berpendapat bahwa promosi dalam pariwisata adalah "arus informasi satu arah yang dibuat untuk mengarahkan calon wisatawan atau lembaga usaha pariwisata kepada tindakan yang mampu menciptakan pertukaran (jual beli) dalam pemasaran produk pariwisata (Utama, 2017). Dengan demikian promosi dalam pemasaran produk pariwisata berperan sebagai pendukung transaksi dengan menginformasikan, membujuk, mengingatkan, dan membedakan produk pariwisata yang dipromosikan dengan pariwisata lainnya. Pada dasarnya pengelola wisata memiliki kewajiban untuk dapat menyampaikan informasi mengenai berbagai informasi yang dimiliki oleh desa wisata terutama potensi wisata. Oleh karena itu, pengelola desa wisata harus jeli dalam memilih komunikator sebagai penyampai pesan terhadap khalayak. Pemilihan komunikator harus didasarkan kepada kriteria dan standar tertentu. Adapun kriteria dan standar tersebut yakni kredibilitas sumber dan daya tarik sumber (Saepudin, Budiono, dan Rusmana, 2017).

Untuk melakukan proses promosi, pengelola desa wisata perlu melakukan langkah-langkah pemasaran produk wisata. Langkah-langkah tersebut yaitu mengidentifikasi produk wisata yang akan dipasarkan, merumuskan produk unggulan terutama produk yang paling menarik dan unik, menetapkan target pasar, perumuskan positioning, membangun identitas (brand), menetapkan harga, dan membangun saluran komunikasi pemasaran. Berikut gambaran langkahlangkah yang harus dilakukan dalam melakukan promosi desa wisata.

a. Mengidentifikasi produk wisata

Produk desa wisata merupakan pengalaman wisatawan selama melakukan aktivitas di desa wisata. Pengalaman diperoleh dari apa yang dilihat, apa yang dilakukan, dan apa yang dibeli oleh wisatawan. Oleh karena itu, langkah pertama yang harus dilakukan oleh pengelola desa wista adalah mengidentifikasi apa yang bisa dilihat, dilakukan, dan dibeli oleh wistawan diarea wisata. Langkahlangkah mengidentifikasi produk wisata pedesaan yaitu;

(1) mendata sebanyak-banyaknya potensi yang dimiliki. Dalam proses pendataan produk wisata, pengelola wisata tidak boleh menganggap sederhana sebuah produk. Sekecil apapun potensi produk wisata harus tetap teridentifikasi. Hal ini dilakukan karena hal yang dianggap sederhana dan biasa di desa belum tentu dianggap biasa oleh para pengunjung. Mungkin saja hal yang biasa dan sederhana di desa justru manjadi hal yang luar biasa di mata para wisatawan. Misalnya, menanam padi mungkin hal yang biasa bagi masyarakat desa, tetapi bisa menjadi luar biasa bagi pengunjung dari kota.

(2) Berfikir inovatif. Dalam proses berfikir inovatif harus mampu membuat sesuatu yang tidak ada menjadi ada. Oleh karena itu, pengelola desa wisata harus mempu melihat potensi yang bisa dikembangkan sesuai dengan minat dan motivasi para pengunjung desa wista. Hal-hal yang dikembangan (sesuatu yang baru) harus bisa memenuhi harapan para pengunjung. Misalnya membuat titik-titik untuk swafoto (selfie), membuat fasilitas istirahat dengan hammock, membuat panggung pertunjukan dll.

b. Merumuskan dan membangun produk unggulan Keunikan produk wisata harus dirumuskan berdasarkan identifikasi produk yang telah kita lakukan. Produk wisata yang ditawarkan harus memberikan manfaat kepada para wisatawan yang menjadi target. Namun demikian didalam membangun produk wisata ini tetap harus memperhatikan daya dukung lingkungan dan sosial supaya desa wisata dapat terus berkembang dan berkelanjutan. Keunikan yang bisa dijual di desa Cibodas adalah lingkugan pertanian dan budaya pertanian yang dimiliki, terutama pembelajaran mengenai pertanian dan olahan hasil pertanian.

Komposisi produk wisata yang dapat dikemas oleh pengelola desa wisata yaitu produk fisik, paket wisata, dan program wisata. (a) Produk fisik terdiri atas atraksi (alam dan buatan) dan fasilitas wisata; (b) Paket wisata merupakan perpaduan dari beberapa tujuan kunjungan wisata dengan satu harga tertentu; dan (c) program merupakan acara-acara (event) yang dapat dibuat oleh pengelola desa wisata, baik secara terjadwal, maupun spontan, seperti acara perlombaan memasak dan olahan hasil pertanian.

c. Menetapkan target pasar

Penetapan target pasar harus disesuaikan dengan produk wisata yang dimiliki terutama produk unggulan yang telah ditetapkan. Dalam mencari segmen pasar, pengelola desa wisata dapat menggunakan berbagai teknik segmentasi seperti segmentasi berdasarkan tujuan wisata, geografis, demografis, psikografis, perilaku atau berbasis produk. Segmentasi yang dibidik harus melewati proses seleksi dan memenuhi kriteria (1) segmen yang dipilih harus yang mampu dilayani oleh pengelola desa wisata (product-market matching); (2) segmen yang 
dipilih harus memperlihatkan pertumbuhan yang menjanjikan; (3) segmen yang dipilih harus lebih efisien dalam menjangkaunya dibanding dengan segmen yang lain.

d. Perumusan positioning

Positioning adalah strategi dalam menanamkan citra desa wisata dibenak para calon wisatawan, agar dipersepsikan unik dibanding dengan desa wisata yang lain. Basis penetapan positioning adalah Unique Selling Proposition yang sudah dirumuskan sebelumnya. Berdasarkan pada Unique Selling Proposition Desa Cibodas mayoritas masyarakat petani sayuran dan olahan hasil pertanian, maka dapat dirumuskan positioning sebagai sentra/ pusat sayuran organik dan olahan hasil pertanian di wilayah Lembang.

e. Membangun identitas (brand)

Desa wisata harus memiliki identitas sebagai ciri khusus dan pembeda dengan produk wisata lainnya. Sebuah identitas desa wisata harus unik dan mudah diingat oleh pasar. Dalam membangun identitas, hal pertama yang harus dilakukan adalah menetapkan merek (brand). Setelah memiliki merek selanjutnya dikampanyekan melalui komunikasi pemasaran. Menurut Keller (2013) dalam menetapkan merek, ada beberapa hal yang perlu diperhatikan yaitu memorability, meaningf ullness, likability, transferability, adaptability, protectability. (1) Memorability; artinya sebuah merek harus mudah diingat, dikenal, terbaca, dan menjadi pusat perhatian. (2) Meaningfullness; merek harus memiliki makna dan esensi dari produk (3) Likability; merek harus berkesan secara estetika (eye-catching). (4) Transferability; merek harus dapat disesuaikan dengan bahasa atau kebiasaan segmen pasar. (5) Adaptability; merek harus fleksibel atau cocok ditempatkan pada segala media, kondisi atau situasi. (6) Protectability; merek jangan sampai diimitasi atau diduplikasi, oleh karena itu harus didaftarkan secara legal.

f. Menetapkan harga

Setelah produk wisata dikemas, pengelola desa wisata harus membuat perhitungan biaya pokok yang harus dikeluarkan dalam menyediakan produk wisata. Biaya pokok ini harus dihitung secara rinci dan cermat baik produk wisata berupa produk satuan, paket, atau pun event. Berdasrkan kepada hasil perhitungan biaya pokok ini pengelola desa wisata dapat menetapkan harga jual setiap produk. Ada beberepa teknik penetapan harga produk terhadap pasar yakni penetrasi, psikologikal, variasi. Berdasrakan kepada hasil pengamatan di lapangan teknik penetapan harga produk wisata yang paling tepat adalah teknik penetrasi. Teknik penetrasi merupakan penetapan harga rendah diawal untuk merangsang kunjungan, dan selanjutnya menaikan harga sampai pada posisi harga normal yang akan ditawarkan secara regular.

g. Membangun saluran komunikasi pemasaran Saluran pemasaran merupakan perantara desa wisata dalam menawarkan produk wisata terhadap para calon wisatawan. Terdapat beberapa saluran yang dapat digunakan oleh pengelola desa wisata yaitu (1) tanpa perantara; artinya pengelola desa wista mendatangkan para wisatawan tanpa bantuan pihak lain atau perantara. Hal ini bisa dilakukan dengan cara mengundang masyarakat, instansi, atau komunitas-komunitas tertentu untuk langsung datang ke lokasi desa wisata, (2) dengan bantuan perantara; artinya pengelola dalam mendatangkan pengunjung melewati perantara seperti agen perjalanan, biro perjalanan wisata, pramuwisata (guide) dan lain-lain. Perumusan pemasaran produk wisata bisa berpijak kepada model komunikasi pemasan (Sutisna , 2001)

Model Komunikasi Pemasaran

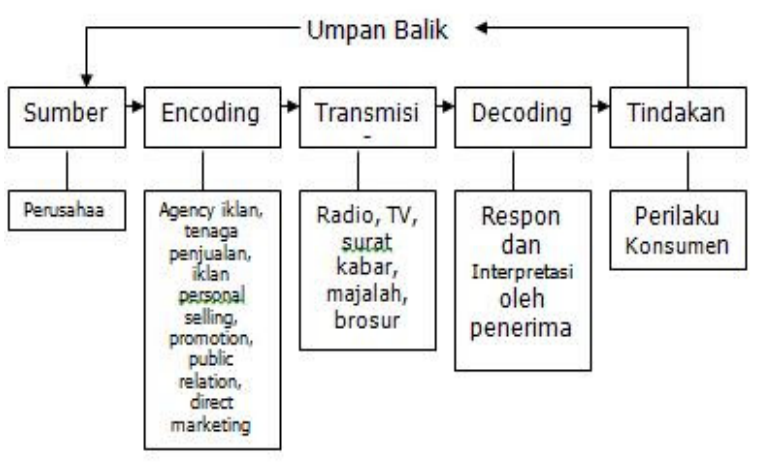

Sumber: Sutisna, 2001: 270

Gambar 2. Model Komunikasi Pemasaran

5. Peningkatan sumberdaya manusia melalui program pendidikan dan pelatihan yang terstruktur dan terorganisai;

Peningkatan kualitas sumber daya manusia para pengelola desa wisata merupakan bentuk pemberdayaan masyarakat. Oleh karena itu, proses pemberdayaan masyarakat dalam pengembangan desa wisata harus memperhatian prinsip-prinsip Enabling, Empowering, Protecting. Enabling yaitu menciptakan suasana atau iklim yang memungkinkan potensi masyarakat berkembang; Empowering yaitu memperkuat potensi atau daya yang dimiliki oleh masyarakat; dan Protecting yaitu mencegah terjadinya persaingan yang tidak seimbang, serta eksploitasi yang kuat atas yang lemah. Prinsip-prinsip tersebut harus menjadi dasar dalam pengmbangan desa wisata.

Untuk pelaksanaan pengembangan sumberdaya manusia dalam pengembangan desa wisata dapat melalui tahapan penyadaran, pengorganisasian, dan penghantaran sumber daya. Proses penyadaran sangat berkaitan dengan proses motivasi masayarakat dalam memahami potensi diri dan lingkungannya. Penghantaran sumberdaya yang dimaksudkan dalam program 


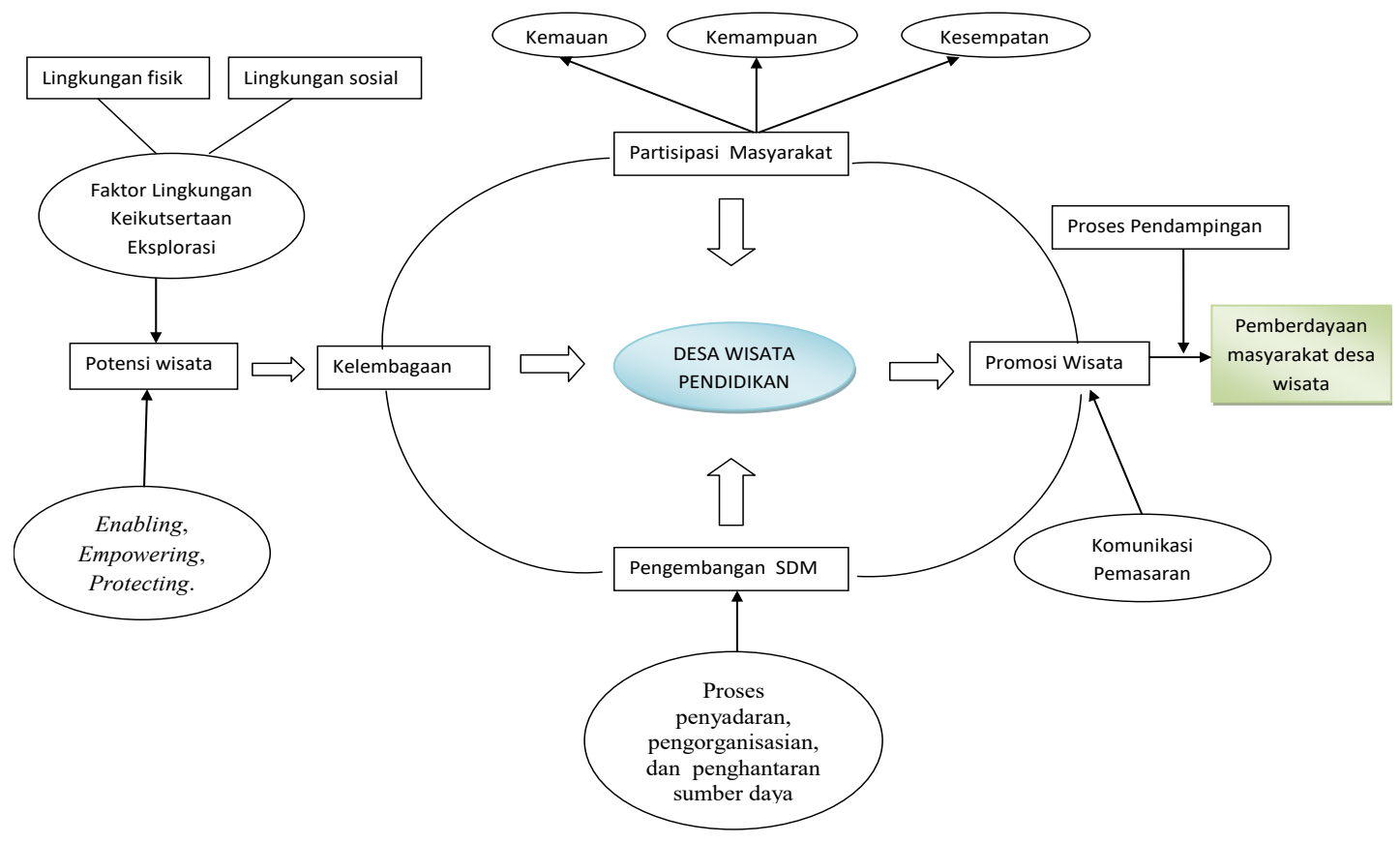

\section{Gambar 3. Strategi Pengembangan Desa Wisata}

ini dapat berupa sumberdaya fisik, materi, atau sumberdaya manusia. Proses penghantaran sumber daya telah dilakukan oleh Pusat Pelatihan Pertanian dan Pedesaan Swadaya (P4S) Mekar Tani Jaya dengan program pembinaan terhadap para petani, para produsen olahan hasil pertanian, dan masyarakat yang mengembangan ekonomi kreatif lainnya.

6. Pendampingan dilakukan secara terstruktur dari lembaga-lembaga/ dinas terkait

Pendampingan dalam program ini merupakan kegiatan pemberdayaan masyarakat dengan menempatkan tenaga pendamping yang berperan sebagai fasilitator, komunikator, motivator, dan dinamisator. Dengan demikian, proses pendampingan merupakan upaya untuk mendorong keterlibatan masyarakat dalam mengembangkan potensi diri dan lingkungannya yang selama ini sudah berjalan namun masih memiliki hambatan. Melalui proses pendampingan diharapkan terjadinya kemandirian baik secara individu maupun kelompok. Salah satu tolak ukur kemandirian adalah kemampuan masyarakat didalam mengambil keputusan.

Pelaksanaan pendampingan berpijak pada prinsip berkelompok, keberlanjutan, dan kemandirian. Prinsip ini menggabarkan kebersamaan didalam membangun kemandirian. Dengan menggunakan konsep "tumbuh dari, oleh, dan untuk kepentingan masyarakat" maka kebersamaan akan terbangun. Hal ini terjadi kerena tumbuhnya rasa kepemilikan bersama terhadap berbagai program yang sedang dikembangkan.

Dengan demikian tujuan utama proses pendapingan adalah tewujudnya kemandirian dibidang material, intelektual, organisasi dan manajemen. Oleh karena itu, fokus pendampingan adalah penyadaran berfikir kritis dan analitis yaitu membiasakan masyarakat untuk mampu mengidentifikasi masalah dan mampu memecahkan masalah secara mandiri. Berdasarkan kepada enam strategi yang telah dikemukan, maka strategi pengembangan desa wisata pendidikan di desa Cibodas Kabupaten Bandung Barat dapat digambarkan sebagai berikut;

\section{SIMPULAN}

Strategi pengembangan desa wisata pendidikan di Desa Cibodas melalui enam strategi yaitu (a) peningkatan partisipasi aktif masyarakat dalam pengemabagan desa wisata mulai dari tahap perencanaan, pelaksanaan, sampai pada tahap evaluasi program; (b) pengembangan desa wisata yang khas berdasarkan kepada potensi alam, sosial, dan budaya masyarakat setempat; (c) pengembagan kapasitas lembaga masyarakat sebagai lembaga pengelola desa wisata (kompepar) untuk membangun koordinasi dan komunikasi antara pemerintah, mesyarakat, dan lembaga donor; (d) pengembangan media promosi wisata melalui berbagai media; (e) Peningkatan sumberdaya manusia melalui program pendidikan dan pelatihan yang terstruktur dan terorganisai; (f) Pendampingan dilakukan secara terstruktur dari lembaga-lembaga/ dinas terkait.

\section{UCAPAN TERIMA KASIH}

Dalam kesempatan ini penulis mengucapkan terima kasih kepada semua pihak yang telah mendukung terlaksananya penelitian ini. Secara khusus penulis mengucapkan terima kasih kepada Dekan Fakultas Komunikasi Unpad, Direktur DRPMI Unpad, Ketua Program Studi Ilmu Perpustakaan Fakultas Ilmu Komunikasi Unpad, Pemerintah Kabupaten 
Bandung Barat, dan Para pengelola Pusat Pelatihan Pertanian \& Pedesaan Swadaya (P4S) Mekar Tani Jaya Desa Cibodas.

\section{DAFTAR PUSTAKA}

Aprilia, F. (2015). Pengaruh Word Of Mouth terhadap Minat Berkunjung Serta Dampaknya Pada Keputusan Berkunjung (Survei Pada Pengunjung Tempat Wisata “Jatim Park 2" Kota Batu). Fakultas Ilmu Administrasi Universitas Brawijaya: Malang. http:// administrasibisnis. studentjournal.ub.ac.id, diakses pada April 2018.

Batubara, B.M. (2017). Hubungan Komunikasi Badan Perwakilan Desa terhadap Partisipasi Masyarakat dalam Pembangunan. Jppuma: Jurnal Ilmu Pemerintahan Dan Sosial Politik Uma (Journal Of Governance And Political Social Uma), 1, (1), 65-76.

Hasanah, N. (2015). Strategi Pengembangan Wisata Edukasi Di Desa Lebak Muncang Sebagai Desa Wisata Di Kecamatan Ciwidey, Kabupaten Bandung (Doctoral dissertation). Bandung: Universitas Pendidikan Indonesia.

Keller, K.L. (2013). Strategic Brand Management Building Measuring and Managing Brand Equity 4th edition. USA: Pearson Education.

Kwartolo, Y. (2007). Mengimplementasikan KTSP dengan pembelajaran partisipatif dan tematik menuju sukacita dalam belajar (Joy in Learning). Jurnal Pendidikan Penabur, 6, (9), 66-80.

Prijono, O.S. \& Pranarka, A.M.W. (1996 Pemberdayaan: Konsep, Kebijakan dan Implementasi. Jakarta: Center for Strategic and International Studies.

Prastiwi, S.(2016). Manajemen StrategiDinas Kebudayaan Dan Pariwisata Kabupaten Bojonegoro Dalm Mengembangkan Potensi Objek Wisata Edukasi Little Teksas Wonocolo. Publika, 4, (11), 1-9.
Putra, A.M. (2012). Konsep Desa Wisata. Jurnal Manajemen dan Pariwisata II, 5, (1), 1-9.

Ritchie, J.B. \& Crouch, G.I. (2003). The competitive destination: A sustainable tourism perspective. Trowbridge: CABI Publishing.

Rodger (1998). Leisure, Learning and Travel, Journal of Physical Education, 69 (4), 28.

Saefulloh, D.A. \& Darma, G.S. (2014). Strategi Marketing Wisata Wedding Sebagai Destinasi Alternatif. Jurnal Manajemen dan Bisnis, 11, (1), 17-34.

Saepudin, E., Budiono, A., \& Rusmana, A. (2017). Karakteristik Pramuwisata Dalam Pengembangan Desa Wisata Agro Di Kabupaten Bandung Barat. Jurnal Ilmu Sosial dan Humaniora, 6, (1), 51-59.

Travers, M. (2001).Qualitative Research Through Case Studies, London: Sage Publications. hal. 9-10.

Nomor, U. U. (10). tahun 2009 tentang Kepariwisataan

Utama, I.G.B.R. (2017). Pemasaran Pariwisata. Yogyakarta: Penerbit Andi.

Yusuf, M. (2016). Pengembangan Kawasan Waduk Mulur Sebagai Kawasan Wisata Edukasi Dan Sport (Doctoral dissertation,). Surakarta: Universitas Muhammadiyah Surakarta.

Yuliastuti, I. A. N. (2013). Partisipasi masyarakat dalam pengelolaan sampah di Kabupaten Badung. E-Jurnal Ekonomi dan Bisnis Universitas Udayana, 2 (6), 374-393.

Yustina. I. \& Naria. E. (2008) Pengaruh Kesempatan, Kemauan, Dan Kemampuan Ibu Terhadap Partisipasi Dalam Pencegahan Penyakit Demam Berdarah Dengue (DBD) Di Kecamatan Baiturrahman Kota Banda Aceh (Master's thesis). Medan: Universitas Sumatera Utara. 